\title{
Spiritual Entrepreneurship: An Approach to Understanding Christian Spirituality in Market Place
}

\author{
Ignatius Bambang Sukarno Hatta, ${ }^{1}$ Romi Lie, ${ }^{2 *}$ \\ ${ }_{1,2}$ Sekolah Tinggi Teologi Jaffray Jakarta, Indonesia \\ *Email: romilie0982@gmail.com
}

\begin{abstract}
Efforts to explore the spirituality of Christian work have become an urgent need, not because they want to compete with the spirituality of work that is currently going on in a secular manner, but as a form of fulfilling the Christian missionary call to "witness, preach the Gospel, and make disciples of all nations." Apart from being an effort to fulfill the call of Christian mission, studying the spirituality of Christian work also helps Christian workers to have a quality work ethic in their workplace, because they do it productively, independently and spiritually. Spiritual entrepreneurship was found to be the right choice that could meet the criteria and forms of Christian work spirituality needed. The method used in this research is literature study, namely by collecting data from books, the Bible, and online journals about Christian entrepreneurship, Christian work spirituality, and Christian work ethic. Spiritual entrepreneurship is the best choice as an embodiment of the spirituality of Christian work, because of the consideration of the underlying principles and values, its distinctive form, and its function and the possibility of a large positive impact it can generate.
\end{abstract}

Key Words: Christian work spirituality, spiritual entrepreneurship, Christian workers.

Article History:

Submitted: July 05, 2021

Revised: Nov. 14, 2021

Published: Jan. 29, 2022

This is an open access article under the CC BY-SA license

\section{INTRODUCTION}

The spiritual life and the daily routine of a Christian are two things that cannot be separated. His fellowship with God, with his Church and his family along with his tasks and daily responsibilites within the scope of his job description could possibly be two activities that he conducts at two different time and places. An employee gives over a third of his time within 24 hours for working. Employment Law No. 13 of 2003 requires that the working hours of an employee is 40 hours a week (Amalia et al., 2017; Charda S., 2016). Assuming that the hours for an employee to work is five days a week, an employee has to fulfill his or her obligation through working 8 hours per day, not including overtime and the time to commute to the office from their place of residence. If the required time needed to travel from home to a work place is two hours, an employee would have to spend at least ten hours in all to deal with his or her work, not including overtime. The ten hours spent every day to go to work should ideally become the time well spent, and for this reason becomes something to be reflected upon. The motivation driving this employee and the inward calling that he has must come from something beyond himself where it is derived from his spiritual values.

Walsh and Middleton (1984) mentioned that one of the primary issues that is currently being dealt with in the Christian community is not the fact that there are not enough doctors, farmers, business owners and musicians. The main problem is that there are not enough Christian doctors, farmers and musicians who can be examples of the Christian faith. In the context of this discussion, there are actually many Christians who are involved in the working class, but it is seldom that he or she incorporates his/her daily tasks as integrated in 
terms of his/her identity as a Christian; or if viewed from a different perspective, the Christian employee has not managed to let go of a dualistic point of view, where Christian faith and secular jobs are two subjects that are worlds apart. Therefore, within the context of a proper understanding of what Christian spirituality actually is can provide a new paradigm and also a better definition about what work is in relation to one's faith, which in the end will inspire and motivate Christians to cultivate a focused mission, vision, and work ethic. The hope is that Christian employees can fulfill and even excel the qualifications required in their respective work places; (Sinamo \& Siadari, 2011). How can Christian farmers and doctors, for instance, develop Christian values in their respective work places (Walsh \& Middleton, 1984)?

It is for those working in such fields and beyond that it is necessary to understand Christian work ethics and ethical principles (Yeniretnowati \& Angin, 2021). This issue is particularly acute for young adult Christians newly entering the workforce. Hopefully they can gain a deeper understanding of the relationship between vocation and faith and incorporate their faith with practical market place work struggles and their actual career journey (Sinamo \& Siadari, 2011).

The employees and Christian professionals who are directly involved in the economy, industries, bussiness, education, health, military and law enforcement, legaslatives and government executives, socio culture realm and community, and other related fields, needs to be encouraged through God's calling into the market place Christian ministry so that they could perform as both skilled workers and also spiritual mentors for others. In order for the market place employee to view his or her own work attitude and behaviour as a form of practical sermon, and to view their office as a form of "church pulpit", thus every person who are present there needs to acknowledge and understand that God is calling them to the market place and they need to respond to God's call through preparing, become willing to obey, have a humility, so that when viewed as whole, there should be no difference between market place professionals and church based ministers when it comes to listening and obeying the call from God to serve (Adi, 2020; Budiyana \& Arifianto, 2021).

From the background described and mentioned above, it can be summed up that this article is presenting a study about spiritual entrepreneurship as an effort to develop a Christan based work ethics. For this reason, the research question is how can a Christian based spirituality be developed in the work place?

\section{METHOD}

The method being used in this research is literature study, which means collecting information from books, the Holy Bible, and online journals about Christian entrepreneurship, Christian work place spirituality, and Christian work ethics. This article is written based on these topics in order to give a broad concept about spiritual entrepreneurship, and afterwards this study will do a synthesis the information obtained from these resources. The result of these analysis is explained descriptively into a detailed and in depth description. The analysis results of the prinsip spiritual entrepreneurship principals can be utilized as a means to formulate a Christian spiritual entrepreneurship and also to display its implication for the Christian spirituality in work. The implication that is being used in this research is explained in a Biblical, practical and theoretical way, so as to provide insight towards a specific finding derived from this research in order for this research to be found useful and can be utilized by many Christian entrepreneurs.

\section{RESULTS AND DISCUSSION}

\section{Understanding Entrepreneurship}

The word entrepreneurship originates from the French word, entreprendre which means to conduct or to strive. This term can be described literally as between-taker or go-between (Hisrich et al., 2008). 
Quoted from the best selling book titled Spiritual Entrepreneurship, Tomatala (2010) described the term entreprendre as someone who organizes and runs a business with a brave attitude and the purpose of obtaining success. With this understanding, people tend to relate enterpreneurship with work that is profit oriented. But this term has a much broader meaning; which can applied to other fields of study. Implied is a high level selfsufficiency, where through this condition there is a well-thought out plan and courage to take action in conducting certain type of work independently by using unique methods, resulting in success and or profitability (Tomatala, 2010).

According to Yasumuro (in Brown \& Rose, 1950), one of the definitions that contains the broadest understanding regarding entrepreneurship was stated by Yamamura who explained that entrepreneurs are a group of individuals who bring about change in methods being used to produce certain types of goods; the group of people refered to here may include government officials, business leaders, bankers, and other groups containing individuals that have proven to be effective instruments to bring forth change.

In addition Yasumuro (in Brown \& Rose, 1950), the idea of entrepreneurship was defined by Schumpeter as a person who was involved the growth of the economy. He defined innovation as an effort to make new combinations or iterations, that bring together various market segments with technology, assuming that through innovation economic changes happen. His view about innovation was later developed, where in his understanding an entrepreneur is equivalent to an innovator. This is the starting point where the study of entrepreneurship was conducted; namely, through the various branches of study including ranging from the economic growth theory to the history of the economy, especially in Harvard University in the early 1950s (Brown \& Rose, 1950; Schumpeter, 1934, 1939; Schumpeter \& Bottomore, 1976).

Mark Casson (in Brown \& Rose, 1950) stated that the theories about entrepreneurship are mostly within the scope of bussiness and economy. However, he defined an entrepreneur as someone who makes decisions that have been approved and well considered relating to coordinating and meeting unlimited desires and needs with very limited resources available. The important thing to be noted here is that this definition is refering to an individual and neither to a team, committee nor organization, because in his opinion only individuals that can make decisions; while on the other hand, decisions made by organizations usually coms from taking collective votes or making a decision based on what the majority wants (Brown \& Rose, 1950).

According to Bygrave and Zacharakis, an entrepreneur is someone who catches an opportunity and builds an organization in order to materialize an opportunity. The process of entrepreneurship includes various functions, activities, and actions that are related, taking advantage of a particular opportunity that develops an organization or develops into an organization (Bygrave \& Zacharakis, 2008).

\section{Defining Christian Spirituality in the Work place}

Sinamo, Indonesia's Ethical Guru, once complained because many Christians tend to not treat their secular jobs in a Christian like manner, meaning not in a holistic way and causing it to be unimportant for them as Christian employees. Christians often only consider making Christian faith as complimentary in relation to their actual jobs and not make their Christian faith as a "spiritual anchor" and the centre of spirituality of their work that can transform and positively impact others (Sinamo \& Siadari, 2011).

In accordance with Sinamo's statement mentioned above about negative behaviours of Christians in the workplace, such as: poor work performance, bringing family and personal problems to work, stealing a company's money, gossiping about co-workers, which causes disharmony in the workplace; laziness and tardiness, becoming an authoritarian leader, and or being a leader who is not 
clever and not knowledgeable, and inter-religious dating among co-workers which results in Christians leaving their faith and embracing another religion. This is not to mention the behaviour of several Christian leaders who are company managers and owners, ranging from those who act in a very worldly way, up to those who are spiritual in their behavior and words, but not in the way they conduct their leadership and managerial practices.

Christian spirituality in the work place is based on plans of peace from God over all His creation which is focused on His Glory (Romans 11:36). His plan for our lives was not just made up on the Creation of man or the Redemption on the Cross, but long before the world was formed (Ephesians 1:4-6). The purpose of God in creating us through the Jesus Christ is to do good works that God has set forth before the beginning of time (Ephesians 2:10). For the Christian employee, the main calling in his job is to glorify God, because everything he has comes from God, and everything began because of the God's initiative.

How can a Christian worker receive the calling from God that he is able to show how important it is for him to bring glory to God, especially in the place where he is working? The Bible teaches believers to present themselves as living sacrifices that are holy and acceptable by God where they will continually experience renewal in their minds through the inner working of the Living Word of God, so that believers can discern what is the will of God, what is good and what is acceptable for Him and perfect in His eyes (Romans 12:1-2).

Allowing God to transform the life of a Christian is equivalent to fully surrendering himself to the Lord. God brings a believer through processes, brings sanctification to the old and sinful nature of man, through imprinting the character of Christ in a Christian's life (2 Corinthians 5:17). The character of Christ that begins to unfold in the life of a believer who has been transformed is a slow but sure process. The Apostle Paul also summoned believers to be rooted and built up in Christ and to be established in the faith (Colosians 2:6-7), because through taking these steps Christ will manifest Himself in and through the lives of the Christians, by means of interacting and working with the people around them (Bambangan, 2019).

Whenever someone does his job with the purpose of bringing glory to God, the consequence is for the believer to bring added value to his job, both through making himself positioned as a person who have been redeemed and saved by God through Jesus Christ, and also through showing positive work performance by managing work, all these should be within the framework of an awareness of bringing glory to God (1 Corinthians 10:31). In the end, bringing glory to God through work will become a a new desire for a Christian whose life have been renewed by God (Latupeirissa, 2019).

Martin Luther and John Calvin, along with the other Protestant Reformed figures, have formulated the doctrine of work in a way contrary to what the Catholic Church taught in the Middle ages. The Catholic church viewed the occupation of human beings merely as the need to get temporary goodness in life and did not give much benefit in reaching eternal goodness and eternal life. Work was considered as only a complement to life. However, the Protestant Reformation caused human professions to be view as being in the centre of God's purpose for human kind. Calvinists saw human occupations as ways to sustain the creative work of God in building a culture that honored God, while followers of Luther saw human occupation as an expression of God's care for His creation (Budiyanto, 2017).

The theology of the Roman Catholic Church however, is not static. Since the writing of the encyclopedia Rerum Novarum by Pope Leo XIII in 1891 and later continued with the Laborem Exercus by Pope John Paul II in 1981, there has been significant development (Tarpin, 2008). Pope Paul VI, for example, commented on Genesis 1:28 that God's command for man to be fruitful and increase in number; fill the earth and conquer it. The Bible, from the very first page, has taught that the whole creation was made for the purpose of man; it 
is the responsibility of man to develop it through clever ways, and with work in order to make it useful. Today, many have shown similarities between the Catholic Church perspective on the law of nature and the Protestant Reformed understanding of common grace, which is God giving wisdom and knowledge to all human beings, including to nonChristians, so that they can enrich the world through their works. Thus, whether it be the social based teaching of the Roman Catholic or the Protestant Reformed teaching, there is no significant difference about the importance of the human work and its relationship to the purpose and will of God (Hardy, 1990; Keller, 2014)

David asserted that God had authority to man to produce wealth and to have the wisdom to manage that wealth for the purpose of expanding God's Kingdom. The Lord desires to have many businesses become businesses for the kingdom, so that these can succeed beyond the world economic system that is decaying and heading towards destruction (David, 2021). Jonathan David's strong influence in transforming the body of Christ in the whole world has brought him some notoriety in becoming an honorary member of the International Who's Who Historical Society.

In terms of the thoughts shared by Yakob Tomatala, he asserted that the works of man should be seen as part of an holistic purpose. Why should the shalom mission be a holistic one? The essence of the shalom mission that is holistic can be described as "one that is whole," that consists of a unity that is integrated along with its detailed aspects. The shalom mission contains an integral unity that is thorough in its essence and attributes, and dynamics that are comparable and consistent in their work mechanisms. The shalom mission is confirmed by God in a Covenant (Promise of Blessing), which is an assurance for the implementation of God's eternal plan. Human occupation should be viewed as part of doing the holistic shalom mission, because the Bible teaches that the Patriarchs of the nation of Israel, as well as other biblical figures were people with an entrepreneurial spirit (Tomatala, 2003, 2010).

Mark D. Hostetter (in Pierce, 2006), once asked a question, "how can a Christian combine his spiritual values in real life workplace?" Christians many times have found that God is calling everyone to portray their faith in a participative and practical way. As far as the context of building business ethics, in creating a corporate culture, and also increasing the enthusiasm to interact socially among the co-workers and their family members, in everything that they do, must be taught to do it with the purpose of bringing glory to God (Pierce, 2006).

Wayne Grudem, stated that business, specifically work, can only be said to be glorifying God when it is run with copying the character and work of God. In his writting titled Business for the Glory of God, Grudem, in a biblical, practical and relevant manner explains how to glorify God in several aspects of business, including: 1) ownership; 2) productivity; 3) work; 4) sales transaction; 5) profitability; 6) money; 7) uneven division of ownership of goods; 8) competition; 9) borrowing and giving loans; 10) the attitude of the heart; 11) impact on world wide poverty (Grudem, 2010).

A thorough and easy to understand explanation is also given by Timothy Keller, about the relation between Christian faith and work. According to Keller the Christian point of view is one that shapes every kind of work that exists. What he is saying is, Christians can only work according the worldview of the Gospel, even though it does not mean they have keep talking about Christianity in the work hour. Several people considers the Gospel as something that already exists in their work. This will mean that the Christian musicians have to always play Christian songs, Christian authors have to always write about repentance and the business owners have to build the company or managers have to work for companies produces only Christian related goods and services. Some Christians in these fields sometimes do well in doing so, but it is clearly a fallacy to think that the Christian worldview "only" operates when it comes 
to overtly Christian activities. Instead, all Christians should think of the Bible as a set of glasses on their face through which they can "see through" everything in the world. The implication is that Christian artists will not be completely tied to profit or mere self-expression and they will tell stories in a wide variety of ways. Christian businessmen will see profit as just one of several goals. They will work with passion in any business and in any workplace. Christian writers can consistently show how destructive it is to have everything other than God first, without always mentioning God's name in their writing (Keller, 2014).

So it can be surmised that Christian work spirituality is an inner quality of a Christian that reflects his fellowship with God and the Bible, and which encourages and moves him to do work and service in order to glorify God, for the sake of bringing good to others and the benefit of himself, which he does according to the way he works to the best of his ability, according to the thoughts, efforts, talents, and resources that God has given him.

\section{Dimensions and Core Qualities of the Christian Worker}

\section{Christian Worker and Personal Salvation}

A Christian worker is certainly very much in touch with his personality. The person who has received the gift of salvation from God in the Lord Jesus Christ through the power of the cross and His resurrection have been reconciled and renewed into a new creation (Colosians 1:15-22)/(Tanuwidjaja \& Darmawan, 2020). Through this a Christian worker believes that God havs bestowed power on his people to become God's children (John 3:16; 1:12). In the end, through his work, there will be an encouragement and new nature for a Christian whose life has been reconciled and renewed by God (Latupeirissa, 2019).

\section{The Christian Worker and Self Transformation}

The Christian worker is a Christian who is diligent and intimate in fellowship with the Holy
Spirit and the Word of God. He believes and lives that the Holy Spirit and the Word of God have the power to transform his inner man from the old to the new and the process of renewing his whole life happens every day because of God's help. To be like Christ is his deepest desire, which is carried every time into his worship and work (Romans 12:1-2; Matthew 5:48).

The transformation that God does is to reshape the life of a Christian worker, which means to surrender the totality of his life to God. In the process, the character of Christ in produced anew in his life (2 Corinthians 5:17). The character of Christ begins to be created in the life of someone who has been changed. In Colossians 2:6-7, The Apostle Paul advised to remain in the Lord, to be rooted, and to be firmly established in Christ and to be firmer in the faith. As a result, through the way he works and interacts with people and his work environment, Christ will manifest Himself in and through his life. (Bambangan, 2019).

\section{The Christian Worker and the Highest Purpose}

The Christian worker is a person who discovers and develops his personal vision and work. The vision becomes strong and continues to strengthen it because it is supported by the Word of God (Tomatala, 2010). When he has to do something, he sees it as an opportunity that God has entrusted to him to work and serve God. His consciousness is built in such a way that every work glorifies God and provides the highest good for others (summum bonum) and bring benefits to himself, encouraging him to put all his best thoughts, efforts and abilities so that his way of working as if done to God and not for humans (Latupeirissa, 2019). Thus he becomes a Christian who respects ethics, acts ethically and adheres to a high work ethic (Matthew 25:14-30; Colossians 3:23; Proverbs 1:7).

\section{The Christian Worker and Work Management}

The work management of a Christian worker is based on the Bible, including all his best thoughts, 
efforts, and abilities that are mobilized in such a way that prioritizes innovation and costs as efficiently as possible. Everything is done in a disciplined manner with maximum effectiveness, so that the work results are always relevant, in accordance with the context and job description, and meets the expectations of the organization/market (Lamentation 3:22-26; Luke 14:28)/(Wiryoputro, 2008).

\section{The Christian Worker and Devotion}

He values the job/profession and the wages he deserves when he is doing a job, because he respects all things that come from God and are done by God. On the one hand, he is not a free-minded person, in the sense that other people cannot get anything from him for free without doing what he wants; and on the other hand he does not try to get something from other people for free. While on the other hand, he is also not a person who pursues profit by placing a "high price" for everything he has, just so that it seems as if when other people need it, it becomes something that is difficult to obtain (The story of Joseph in the Book of Genesis; the story of Elijah in the Book 1 Kings 19). The statement made by Jesus in Matthew 10: 8 says, "you have receive it for free, so give it away freely." This means that all the gifts that God has given to believers to serve should not be used for the sake of profit. But at the same time believers as servants of God must teach the congregation they serve, that they must work in the business world to fulfill their needs. (Lynn, 1965; Wirawan, 2002) by not allowing business owners to treat themselves like cash cows, giving insufficient wages not commensurate with their professional abilities, while the company's assets and net profits have increased significantly.

\section{The Christian Worker and Work Satisfaction}

Job satisfaction is something that is important to him. The measure of job satisfaction is not just a satisfaction he feels emotionally, euphoric and egocentric, but it is indicated by two things, namely: First, the confirmation he receives through faith, that God is pleased with his work, the way he works and the results of his work. Witherington (2021) says that God has called and bestowed His grace upon Christian workers with important and meaningful duties and responsibilities, encouraging them to do so for the glory of God. Work is a service to God. In this case, it must be seen how the work carried out, no matter how small or indirectly, contributes to the realization of God's purpose for mankind. Second, people derive the highest good and benefits from a Christian's work. This means encouraging and moving a Christian to do work and service to glorify God, for the sake of bringing good to others and for the benefit of himself, which he does in the best and fullest way, according to the thoughts, efforts, abilities, talents, and resources that God has given (Latupeirissa, 2019).

\section{The Christian Worker and the Dwelling Place}

Because Biblical truth has always been the yardstick and spectacle for his outlook on all things connected with his work and his entire life, he knows "where to go" when faced with difficult and complex problems and dead ends in his work. He realizes that his spiritual position as a child of God who has been awarded the victory cannot be shaken by any heavy problems in his work (John 1:12). God is his refuge. God's presence has always been a place for him to calm down and receive confirmation and new strength; while God's Word became God's tool for him to get up and face his "war" again with full awareness that God must be with him. The Sabbath for him is not simply "one day" when he takes a break from work for one or two days a week, but a "resting place" for taking some quiet time (Budhi, 2021), which he can enter at any time. He can spend quiet time during office breaks and have lunch with fellow believers who are mature enough in their faith and thoughts (Pangumbahas \& Napitupulu, 2021); or it may also occur through interactions with superiors or coworkers who do not share the same faith, but he has been shown to often build others up at work through the experience, advice and technical assistance he shares. However, it is clear and certain that a manual 
laborer must make good use of his rest time. It would be perfect if the moment was spent with family, in order to build togetherness and quality relationships. A good rest will allow him to return to work refreshed and fully prepared, but a growing relationship will provide strong support for his soul.

\section{The Christian Worker and Family}

A Christian worker knows the exact address of his home. What is meant is that, first, he will always put his own family first, and doesn't care how much his co-workers or business colleagues persuade him to stop for a while somewhere after work. If it is unrelated, then his decision will be straight home. Second, he knows exactly where his spiritual home is, who his spiritual parents and family are in Christ. All the great people used by God to fulfill His will were children of a spiritual father/spiritual parents. For example Isaac had Abraham, Jacob had Isaac, Joseph had Jacob, Moses had Jethro, Joshua had Moses, David had Samuel, Esther had Mordecai, Elisha had Elijah, the 12 disciples were led by Jesus, and Timothy and Titus had Paul. Spiritual parents are not perfect people; he is still undergoing the process of forming and perfecting God. However, the presence of spiritual parents for us is very important because it is a biblical principle and becomes one of the spiritual tools for God to protect (cover) and make a covenant of His blessing (covenant) with someone in Jesus Christ, which is based on covenants.

The importance of this principle is felt by a number of figures in the general public, which they have practiced in other forms and terms such as spiritual advisor, spiritual teacher/guide or a term that is currently being developed is life coach. For example, Jim Rhon who became a teacher for Anthony Robbins (Intarti, 2015). then Anthony Robbins became a teacher, motivator, and spiritual advisor for many figures such as Nelson Mandela, Bill Clinton, Michael Jordan and Tung Desem Waringin. Andrie Wongso became an advisor and motivator for many people and corporations, including the Indonesian national badminton team, and Candra Wijaya became one of his success stories (Fawwaz, 2020; Shaleh et al., 2014). See also Rhonda Byrne and other contributors to The Secret who have so many followers because of the influence of their writing which is considered enlightening (Nurdin, 2012).

Are they all considered a "religious leader" for their followers? Researchers suspect that they do not consider these advisers to be their religious leaders. However, looking at the evidence that every motivation, guidance and advice given by these advisors influences the considerations and decisions of followers in the business world and at the same time affects their career, family and personal life, it can be said that these advisors play an important and contributing role in the lives.

\section{The Christian Worker and Money}

A Christian worker is a person who loves God and others. Every worker must get a steady income. The success he achieved and the income he received was seen as a blessing from God and the support of the people who had been praying and encouraging him from behind.

How did he express his gratitude to God? First, he regularly returns tithes as a sign of respect to God (Malachi 3:7-12), just as Abraham honored God by giving a tithe to Melchizedek, the Priest of God Most High (Genesis 14:18-20)/(Christiawan, 2018; Sarjono, 2020). Second, he involves himself in missionary service. Third, he routinely fulfills his obligations to the state through the taxes he pays (Sahardjo, 2021). Fourth, he is someone who understands wisely how to manage finances for himself, his family and work (Sari et al., 2019).

\section{The Christian Worker and Witnessing}

When glorifying God and doing good to others is the highest goal, witnessing is the means. God's command in Matthew 28:19-20 clearly says,

Go therefore, make disciples of all nations and baptize them in the name of the Father and of the Son and of the Holy Spirit, and teach them to do all things that I have commanded you. 
And behold, I am with you always, even to the end of the age.

This great commandment must be the basis that motivates us to be His witnesses (Darmawan, 2019). The researcher adopted the approach described by Tomatala (2003) in the book Theology of Mission, as a possible way to do it, namely: 1) Presence or presence approach, namely, realizing quality work and the ability to carry and position oneself well through "presence" as a testimony in the social work environment; 2) The task of proclamation or proclamation, namely proclaiming the LORD Jesus Christ, the Savior as the core focus of the gospel message. Because this is a very sensitive thing to do in the work environment, even among Christian coworkers, patience and wisdom are needed so as not to cause social clashes. It is very possible that this is done outside working hours so as not to disturb, in the midst of light activities; 3) Persuasion, namely

\section{REFERENCES}

Adi, S. (2020). Kewirausahaan dan Panggilan Kristen: Sebuah Pendekatan InterpretatifDialogis, Sosio-Historis dan Teologis. KURIOS (Jurnal Teologi Dan Pendidikan Agama Kristen), 6(1), 18. https://doi.org/10.30995/kur.v6i1.123

Amalia, A., Ginting, B., Agusmidah, A., \& Journal, Y. Y. (2017). Analisis Yuridis Perjanjian Kerja Waktu Tertentu Berdasarkan Undangundang Ketenagakerjaan dan Hukum Perjanjian. USU Law Journal, 5(1), 66-76.

Bambangan, M. (2019). Perspektif Teologis Terhadap Etika Bisnis Kristen. JURNAL LUXNOS, 5(2), 135-146. https://doi.org/10.47304/JL.V5I2.22

Brown, J., \& Rose, M. B. (Eds.). (1950). Entrepreneurship, Networks and Modern Business. Manchester University Press.

Budhi, S. S. (2021). Makna Teologi Istirahat Dan Perkembanganya Dalam Kitab-Kitab Kanonik. Predica Verbum: Jurnal Teologi Dan Misi, 1(2), 138-154. https://doi.org/10.51591/predicaverbum.v1i2. efforts to convince listeners of the truth of the gospel 4) Incorporation into the Body, which involves every new believer into the church or congregation.

\section{CONCLUSION}

The spirituality of Christian work is understood as the inner quality of a Christian that reflects his fellowship with God and the Bible, which encourages and moves him to do work and service for the sake of glorifying God, for the good of others, and for the benefit of himself.

Spiritual entrepreneurship is the best choice for an embodiment of the spirituality of Christian work, because of the consideration of the underlying principles and values, its distinctive form, and its function and the possibility of a large positive impact in the world.

27

Budiyana, H., \& Arifianto, Y. A. (2021). Pelayanan Holistik Melalui Strategi Entrepreneurship bagi Pertumbuhan Gereja Lokal. Jurnal EFATA: Jurnal Teologi Dan Pelayanan, 7(2), 116-127. https://ejournal.sttiman.ac.id/index.php/efata/article/v iew/46

Budiyanto, L. (2017). Tinjauan terhadap Konsep Kerja Kristen dalam Perspektif Reformed [Sekolah Tinggi Teologi Amanat Agung]. http://repository.sttaa.ac.id/id/eprint/558/

Bygrave, W., \& Zacharakis, A. (2008). Entrepreneurship. John Wiley \& Sons Inc.

Charda S., U. (2016). Karakteristik UndangUndang Ketenagakerjaan Dalam Perlindungan Hukum Terhadap Tenaga Kerja. Jurnal Wawasan Yuridika, 32(1), 1. https://doi.org/10.25072/jwy.v32i1.86

Christiawan, A. F. (2018). Persepuluhan Menurut Maleakhi 3:7-12. Missio Ecclesiae, 7(1), 2867. https://doi.org/10.52157/me.v7i1.81

Darmawan, I. P. A. (2019). Jadikanlah Murid: 
Tugas Pemuridan Gereja Menurut Matius 28:18-20. Evangelikal: Jurnal Teologi Injili Dan Pembinaan Warga Jemaat, 3(2), 144153. https://doi.org/10.46445/ejti.v3i2.138

David, J. (2021). Naluri Bisnis untuk Menghasilkan

Uang: Dari Krisis sampai Pemulihan, Dari Pemulihan sampai ke Terobosan. Adonai Publishing House.

Fawwaz, N. (2020). Klub Candra Wijaya International Badminton Center Jakarta = The role of brand endorser in interesting communities in following bulutangkis training in Candra Wijaya ... [Universitas Pelita Harapan]. http://repository.uph.edu/10038/

Grudem, W. (2010). Business for the Glory of God: Ajaran Alkitab Tentang Kebaikan Moral Bisnis. Visi Press.

Hardy, L. (1990). The Fabric of This World: Inquiries into Calling, Career Choice, and the Design of Human Work. Eerdmans.

Hisrich, R. D., Peters, M. P., \& Sheperd, D. A. (2008). Entrepreneurship Kewirausahaan (7th ed.). Salemba Empat.

Intarti, W. S. (2015). The Power of Librarian Management. Media Pustakawan, 22(3). https://doi.org/10.37014/medpus.v22i3.212

Keller, T. (2014). Apakah Pekerjaan Anda Bagian dari Pekerjaan Allah?: Menghubungkan Pekerjaan Anda dengan Rencana Allah bagi Dunia. Perkantas.

Latupeirissa, J. (2019). Etika Bisnis Ditinjau Dari Perspektif Alkitab. PASCA: Jurnal Teologi Dan Pendidikan Agama Kristen, 15(1), 8-15. https://doi.org/10.46494/PSC.V15I1.63

Lynn, K. (1965). The Profession in America. Houghton Mifflin.

Nurdin, M. (2012). The Law Of Attraction dan Doa dalam Islam. Dialogia: Jurnal Studi Islam Dan Sosial, 10(2), 227-240. http://jurnal.iainponorogo.ac.id/index.php/dia logia/article/view/314

Pangumbahas, R., \& Napitupulu, P. A. (2021). Sabat Dan Bekerja: Suatu Perspektif Teologi Kerja. RERUM: The Journal of Biblical
Practice, l(1), $47-61$.

https://jurnal.moriah.ac.id/index.php/rerum/ar ticle/view/1

Pierce, G. F. A. (2006). Spirituality @ Work: 10 Cara Menyeimbangkan Hidup Anda di Tempat Kerja. Kanisius.

Sahardjo, H. P. (2021). Orang Kristen dan Kehidupan Politik. TE DEUM (Jurnal Teologi Dan Pengembangan Pelayanan), 3(2), $217-$ 227. https://doi.org/10.51828/td.v3i2.96

Sari, E. C., Ismanto, B., \& Luhsasi, D. I. (2019). Perilaku Konsumtif: Literasi Keuangan dan Gaya Hidup Ibu Rumah Tangga. Ecodunamika, 2(2). https://ejournal.uksw.edu/ecodunamika/articl e/view/2572/1284

Sarjono, N. (2020). Kajian Teologis Tentang Persepuluhan. JURNAL LUXNOS, 6(1), 6471. https://doi.org/10.47304/jl.v6i1.33

Schumpeter, J. A. (1934). The Teory of Economic Development. Cambridge.

Schumpeter, J. A. (1939). Business Cycles: A Theoretical, Historical and Statistical Analysis of the Capitalist Process.

Schumpeter, J. A., \& Bottomore, T. (1976). Capitalism, Socialism and Democracy (T. Bottomore (Ed.)). George Allen \& Unwin.

Shaleh, H. I., Murtomo, B. A., \& Wijayanti, W. (2014). Pusat Pendidikan dan Pelatihan Bulutangkis Usia Dini di Semarang.

Sinamo, J., \& Siadari, E. E. (2011). Teologi Kerja Modern dan Etos Kerja Kristiani. Institut Dharma Mahardika.

Tanuwidjaja, S., \& Darmawan, I. P. A. (2020). Bisnis dalam Perspektif Iman Kristen. THRONOS: Jurnal Teologi Kristen, 1(1), 8698.

http://ojs.bmptkki.org/index.php/thronos/artic le/view/5

Tarpin, L. (2008). Analisis Kritis atas Rerum Novarum (1891) dan Octogesima Adveniens (1971) dari Perspektif Perempuan. MELINTAS, 24(2), 253-284. https://doi.org/10.26593/MEL.V24I2.952.253 
$-284$

Tomatala, Y. (2003). Teologi Misi. YT Foundation.

Tomatala, Y. (2010). Spiritual Entrepreneurship: Anda Juga Bisa Menjadi Entrepreneur Rohani. YT Foundation.

Walsh, B. J., \& Middleton, J. R. (1984). The Transforming Vision: Shaping a Christian World View. InterVarsity Press.

Wirawan. (2002). Profesi dan Standar Evaluasi. Yayasan Bangun Indonesia \& UHAMKA
Press.

Wiryoputro, S. (2008). Dasar-dasar Manajemen Kristiani. BPK Gunung Mulia.

Witherington, B. (2021). Kerja: Sebuah Perspektif Kerajaan Allah. Perkantas.

Yeniretnowati, T. A., \& Angin, Y. H. P. (2021). Integrasi Iman dan Pekerjaan sebagai Sebuah Strategi Misi. DIDASKO: Jurnal Teologi Dan Pendidikan Kristen, 1(1), 1-11. https://doi.org/10.52879/DIDASKO.V1I1.3 